\title{
Phenotypic, Genetic and Biochemical Characterization of Five Tunisian Varieties of Chickpea
}

\author{
Mongi Melki (Corresponding author) \& Abir Gsouri \\ University of Jendouba, Higher School of Agriculture of Kef, 7119 Kef, Tunisia \\ Tel: 216-5353-4277Ｅ-mail: melki.mongi@iresa.agrinet.tn \\ Mariem Bouhadida \\ University of Carthage, Field Crop Laboratory \\ National Institute for Agricultural Research of Tunisia, Tunisia \\ Hnya Chograni \\ University of Jendouba, Higher School of Agriculture of Kef, 7119 Kef, Tunisia
}

Mohsen Rezgui

University of Carthage, Laboratory of Science and Agronomic Techniques

National Institute for Agricultural Research of Tunisia, Tunisia

Received: January 3, 2017 Accepted: January 31, 2017 Published: February 24, 2017

doi:10.5296/jas.v5i1.10808 URL: https://doi.org/10.5296/jas.v5i1.10808

\begin{abstract}
Five Tunisian varieties of Kabuli chickpea were characterized based on agro morphological, molecular and biochemical parameters to investigate their genetic variability and yield potential. Randomized complete block design field trials were carried out in the upper semi-arid region of Kef in Tunisia during the 2013-2014 seasons. Data analysis showed significant differences between genotypes for several parameters. The results indicated that these genotypes could be set into two different groups. The first group composed of Bochra and Chetoui genotypes. Kasseb, Neyer and Beja1 were in the second group. Genotypes in each group were closely related to each other according to their common morphological characters such as pod number, one hundred seeds weight and yield. Chetoui and Kasseb
\end{abstract}


varieties are later in comparison to other varieties. Genetic diversity was studied using simple sequence repeat (SSR) markers. Four loci (TA64, TA71, TA96, TA194) were multiallelic. Whereas while two loci (TA72, GAA47) were monomorphic. Polymorphism analysis showed a phylogeny related to genotypes differentiation according to their relatives, origin and several morphological characters. Bochra variety had high amino acids content followed by Chetoui variety. All the varieties were deficient in sulfur amino acids. Chickpeas protein contents were variable and high ranging from $18 \%$ to $25 \%$.

Keywords: Chickpea, diversity, Genetic variability, Polymorphism

\section{Introduction}

Food legumes, including Faba beans, peas, lentils, beans and chickpeas, are considered very important source of vegetable protein that can correct deficits in animal protein. In addition to their importance in peoples' diet, they have a particular interest in crop rotation, diversity of production and environment protection by limiting the use of pesticides and nitrogen fertilizers (Melki et al., 2011).

In Tunisia, grain legumes cultivated areas are still limited. It does not exceed 80000 ha (Kharrat \& Ouchari, 2011), which is $0.002 \%$ of the total agricultural lands and $4.23 \%$ of field crops including cereals, legumes and fodders. Average annual production of pulses from 1990 to 2010 was 67000 tons (DGPA, 2011).

Chickpeas (Cicer arietinum L.), are important grain legume crops in Tunisia, coming in second position after faba beans. Most chickpea areas are located in the northern Tunisia, particularly Beja, Jendouba, Nabeul, Bizerte and Mateur regions where the climate is humid to sub-humid. It is grown on about 19636 ha with an average yield of $956 \mathrm{~kg} \mathrm{ha}^{-1}$ and a total production of 7700 tons $^{-1}$ (Eva et al., 2015). Low rainfall during the spring season in the Mediterranean region during flowering and pod formation of chickpeas has been a limiting factor for achieving high production.

Chickpeas yields were improved since the introduction of winter chickpeas, during the 1999-2000 cropping season, with an average yield that went up from 6.2 quintals $\mathrm{ha}^{-1}$ in 1987-1999 to 7.45 quintals ha $^{-1}$ in 1999-2007 (DGPA, 2008). New varieties were developed by researchers at ICARDA (International Center for Agricultural Research in the Dry Area) using a new concept of winter sowing that allows chickpeas to take advantage of winter rains to improve vegetative growth, biomass and yield production (Singh \& Hawtin, 1979; Ben Mbarek, 2011). However, this approach requires genotypes tolerant to cold and fungal diseases especially those caused by Ascochyta rabiei f.sp.ciceris (Singh et al., 2008). In Tunisia, since 1987, seven new varieties of chickpea have been registered in the official catalogue of vegetables since 1987 in Tunisia (IRESA, 2014).

The objective of this study was to characterize a Tunisian collection of five chickpea varieties. Priority was given to most adopted varieties in the country. It focuses mainly on the agronomic, phenologic, genetic and biochemical parameters of these genotypes. These results will be added to gene bank database besides helping farmer to choose high yielding chickpea varieties. 


\section{Materials and Methods}

\subsection{Plant Material}

Five chickpea (Cicer arietinum L.) varieties used in the study are presented in Table 1.

Table 1. Pedigree and origins of five Tunisian chickpea varieties

\begin{tabular}{lcc}
\hline \multicolumn{1}{c}{ Varieties } & Pedigree & Origin \\
\hline Kassab & FLIP83-46C & Improved line from ICARDA \\
Chetoui & ILC3279 & Russia \\
Beja1 & (Amdoun1xILC3279) xILC200 & ICARDA - INRAT \\
Bochra & FLIP84-79C & Improved line from ICARDA \\
Neyer & FLIP84-92C & Improved line from ICARDA \\
\hline
\end{tabular}

Source: Bouhadida et al. (2015)

\subsection{Experimental Design and Measured Parameters}

Field trials using five chickpea varieties were conducted in a randomized complete block design with three replications at the upper semi arid region of Kef in Tunisia during the 2013-2014 seasons.

The number of flowers by plant, precocity (days between flower emergence and $50 \%$ flowering), plant height, number of ramifications and grain number by plant, were measured using ten sampled plants in each plot. Mean weight of 100 grains was estimated from collected grains of each variety within each block. Protein contents were estimated by multiplying nitrogen contents by 6.25 (AOAC, 1990) and nitrogen were measured by Kjeldahl method. Amino-acids fraction was estimated from one sample for each variety with no replication. The analyses were carried out at the National Institute of Agronomic Research Laboratory using HPLC-FLD (Buha et al., 2011).

\subsection{Molecular Analysis}

The genomic DNAs were extracted from young leaves for all chickpea genotypes according to the extraction protocol described by Saghai-Maroof et al. (1984) with some modifications: Approximately $0.5 \mathrm{~g}$ of young leaves of each genotype were recovered in a mortar and ground with the addition of liquid nitrogen until fine powder. Later, $600 \mu$ of extraction buffer (1\% CTAB, 10mM EDTA, $50 \mathrm{mM}$ Tris Base ), $0.7 \% \mathrm{NaCl}, 1 \%$ beta-mercaptoethanol, $\mathrm{pH}=8$ ), previously prepared and preheated in a water bath at $65^{\circ} \mathrm{C}$ for $15 \mathrm{~min}$ were added to the powder. The mixture was homogenized and then transferred to a sterile Eppendorf tube and incubated at $65^{\circ} \mathrm{C}$ for $30 \mathrm{~min}$ to $1 \mathrm{~h}$ by applying periodic agitation every 10 to $15 \mathrm{~min}$. A volume of $600 \mu \mathrm{L}$ of chloroform /isoamyl alcohol (24:1) was added. After homogenization 


\section{Mll Macrothink}

Journal of Agricultural Studies ISSN 2166-0379 2017, Vol. 5, No. 1

the tubes were centrifuged at $10000 \mathrm{~g}$ for $10 \mathrm{~min}$. The recovered supernatant was transferred to another eppendorf tube and an equivalent volume of chloroform /isoamyl alcohol (24:1) was added. A second centrifugation of $10000 \mathrm{~g}$ for $10 \mathrm{~min}$ was made. The supernatant was recovered and the DNA precipitated by adding cold isopropanol (2/3 the volume of supernatant). At this stage, a slight agitation was done to see the DNA strands. The tubes were incubated at $-20{ }^{\circ} \mathrm{C}$ for $1 \mathrm{~h}$ minimum. Thereafter, it was cold centrifuged for $20 \mathrm{~min}$ at $10000 \mathrm{~g} / \mathrm{min}$. The supernatant was decanted and the pellet appeared at the bottom of the tube was washed with $500 \mu 1$ of $70 \%$ cold ethanol. After a final cold centrifugation of $10000 \mathrm{~g} / \mathrm{min}$ for $10 \mathrm{~min}$, the aqueous phase was removed and the DNA pellet was allowed to dry in the open air. The DNA pellet was finally suspended in $200 \mu \mathrm{l}$ of TE (Buffer re-suspension: 10 $\mathrm{mM}$ Tris- $\mathrm{HCl}, 1 \mathrm{mM}$ EDTA, $\mathrm{pH}=7.5$ ) and stored at $-20^{\circ} \mathrm{C}$ until future use.

Assessment of the DNA concentration and quality was made by the migration of $5 \mu \mathrm{l}$ of each DNA sample mixed with $5 \mu \mathrm{l}$ of loading buffer $(15 \mathrm{ml}$ glycerol $(80 \%), 0.1 \mathrm{~g}$ of blue bromophenol, $0.1 \mathrm{~g}$ of xylene cyanol and completed to $40 \mathrm{ml}$ with distilled water), on a $0.8 \%$ agarose gel. The amount of DNA present in a suspension was estimated by measuring the optical density (OD) at $260 \mathrm{~nm}$.

The DNA concentration was adjusted to $50 \mathrm{ng} / \mu \mathrm{l}$ for all samples. PCR were made by bringing together in one tube $(0.2 \mathrm{ml})$ the various components of the reaction mixture for a total volume of $20 \mu \mathrm{l} /$ tube. The prepared PCR were placed in a thermal cycler type "MultiGene OPTIMAX". Amplifications of DNA of the genotypes studied were provided by a pre-denaturation step at $95{ }^{\circ} \mathrm{C}$ for $1 \mathrm{~min}$, followed by 35 cycles consisting of: a denaturation phase of $2 \mathrm{~min}$ at $94{ }^{\circ} \mathrm{C}$, a hybridization stage 50s corresponding to the annealing temperature for each pair of primers (Table 2) and a final extension for $50 \mathrm{~s}$ at $60{ }^{\circ} \mathrm{C}$ for the pattern of markers (TAA) and at $72{ }^{\circ} \mathrm{C}$ for those pattern (GAA). The last cycle was followed by a final elongation of $5 \mathrm{~min}$ at $60^{\circ} \mathrm{C}$ or $72{ }^{\circ} \mathrm{C}$ depending on the marker pattern to be amplified (or TAA GAA).

Table 2. Characteristics of the eight SSRs markers used for the characterization of the five Tunisian chickpea varieties

\begin{tabular}{ccccc}
\hline Code locus & Motif & Ta $\left({ }^{\circ} \mathbf{C}\right)$ & size & Reference \\
\hline TA27 & (TAA) 21 & 56 & 241 & Winter et al. 1999 \\
\hline TA59 & (TAA)29 & 56 & 258 & Winter et al. 1999 \\
\hline TA64 & (TAA)39 & 56 & 239 & Winter et al. 1999 \\
\hline TA71 & (AAT)32 & 56 & 225 & Winter et al. 1999 \\
\hline TA72 & (ATT)36 & 56 & 256 & Winter et al. 1999 \\
\hline TA96 & (AT)3(TTA)30(AT)3 & 56 & 275 & Winter et al. 1999 \\
\hline TA194 & (TTA)21 & 56 & 132 & Winter et al. 1999 \\
\hline GA447 & (GAA)11 & 56 & 169 & Winter et al. 1999 \\
\hline
\end{tabular}




\section{I Macrothink}

Separation of amplification products was performed by electrophoresis on polyacrylamide gel. PCR products were mixed with formamide buffer (dye compound by $9.8 \mathrm{ml}$ of formamide, 200 $\mu 1$ EDTA $(0.5 \mathrm{M}, \mathrm{pH}=8), 0.1 \mathrm{~g}$ xylene cyanol and $0.1 \mathrm{~g}$ bromophenol blue), and was denatured for $3 \mathrm{~min}$ at $95^{\circ} \mathrm{C}$ and then transferred immediately into ice. The revelation was made in an ethidium bromide bath. Visualization of band patterns was made under UV (ultra violet) using the Gel Doc "Vilber Lourmat". The estimation of the size of amplified bands was made by the molecular weight marker 25bp DNA Step Ladder Promega. Later, the software Ecapt was used to analyze the different patterns obtained after the amplification with different DNA samples of five genotypes studied using the 8 SSR markers.

The evaluation of the information obtained from the eight SSR markers was used to evaluate the following parameters: number of alleles per locus $(\mathrm{N})$, the real number of alleles $(\mathrm{Ne})$ per locus ( $\mathrm{Ne}=1 / \sum \mathrm{p}_{\mathrm{i}}{ }^{2}$, where $\mathrm{p}_{\mathrm{i}}$ is the frequency of the $\mathrm{i}^{\text {th }}$ allele). The capacity of a marker to distinguish between cultivars was chosen randomly and was estimated for each locus by calculating the discriminating power (PD) per the formula below:

$$
P D=1-1 / \sum g_{i}^{2}
$$

where $\mathrm{g}_{\mathrm{i}}$ is the frequency of the $\mathrm{i}^{\text {th }}$ genotype (Kloosterman et al., 1993).

Dendrograms were built from binary matrices (0/1) (absence/presence) using the "Unweighted Pair Group Method Average" ( UPGMA ). The similarity between cultivars was calculated using the Dice coefficient (Nei \& Li, 1979) and analyzed with SIMQUAL software of NTSYS pc V.2.1 program (Rohlf, 2000).

\subsection{Statistical Analysis}

The analysis of variance was used to compare varieties means for all measured parameters. Data was analyzed using SAS software. However, amino acids were measured on a single sample for each variety and have not been statistically analyzed.

\section{Results and Discussion}

\subsection{Morphological Characterization of Chickpea Varieties}

Statistical analysis indicated high significant differences between the five chickpeas varieties for their number of flowers. Kasseb, Neyer and Chetoui varieties had the highest number of flowers per plant with values 55, 43 and 35, respectively. Beja1 and Bochra genotypes had the lowest values of 25 and 24 flowers per plant (Figure 1). 


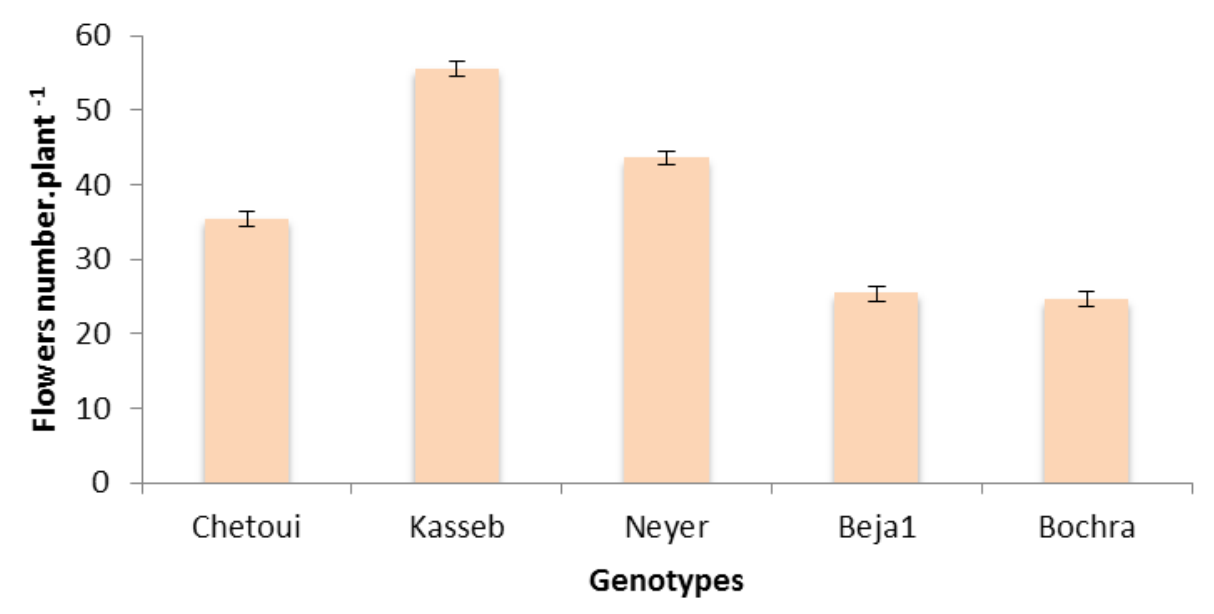

Figure 1. Number of flowers/plant of five chickpea varieties cultivated at Kef region during 2013-2014 season. The bars indicate standard error of the mean

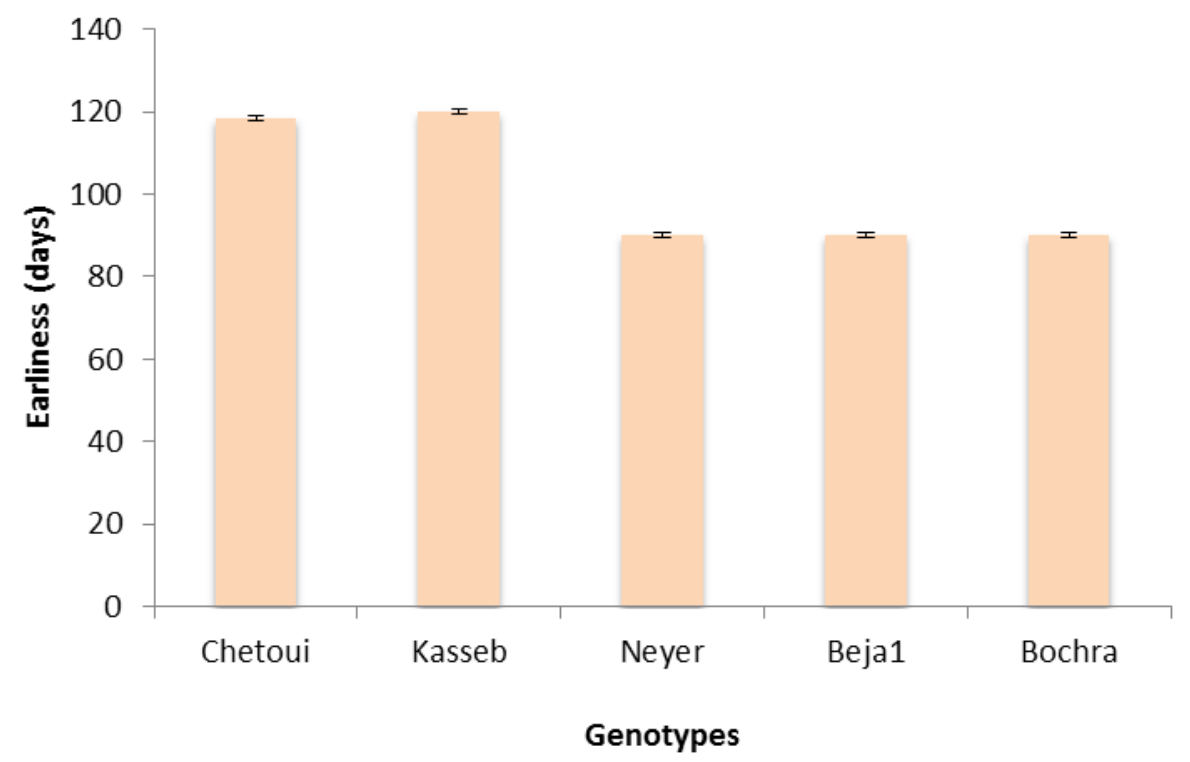

Figure 2. Earliness (days) of five chickpea varieties cultivated at Kef region during 2013-2014 season. The bars indicate standard error of the mean

All chickpea genotypes were similar for flower color which was white with no anthocyanin. This phenomenon is specific to the type "Kabuli" as reported in previous studies (Khan et al., 2011).

Earliness in the varieties ranged from 90 to 120 days (Figure 2). High significant differences were found between genotypes. Bochra, Beja1 and Neyer varieties were early with 90 days time to $50 \%$ flowering while Kasseb and Chetoui varieties were late with 120 days. The present results are similar to those reported by Khamassi et al. (2014). 


\section{Macrothink}

Plant height showed a set of three groups. Chetoui had longer stems exceeding $50 \mathrm{~cm}$ followed by Bochra with an average height of $44 \mathrm{~cm}$. Kasseb was the shortest with $27 \mathrm{~cm}$ while Neyer and Beja1 were intermediate (Figure 3). Our results were consistent with those reported by El Felah \& Kharrat (2014).

High significant differences were found between genotypes for their number of stem secondary branches (Figure 4). Neyer recorded the highest (7 branches) while Chetoui and Bochra had the lowest values of 3 branches. These results were consistent with those reported by Khamassi et al. (2014).

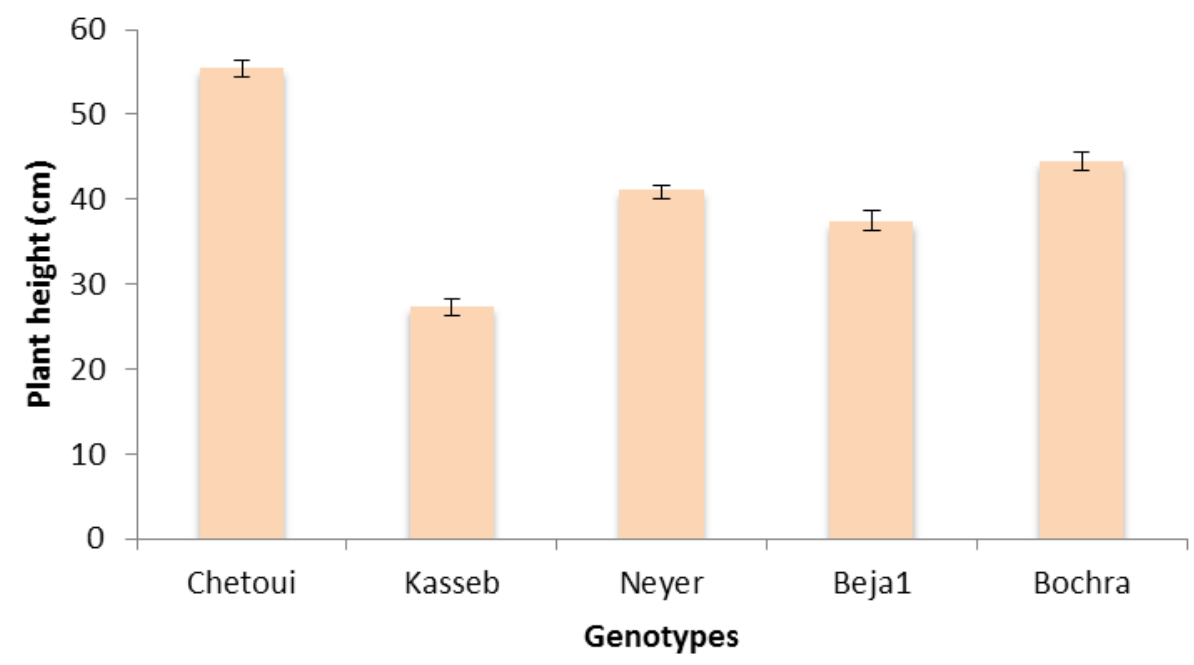

Figure 3. Plant height of five chickpea varieties cultivated at Kef region during 2013-2014 season. The bars indicate standard error of the mean

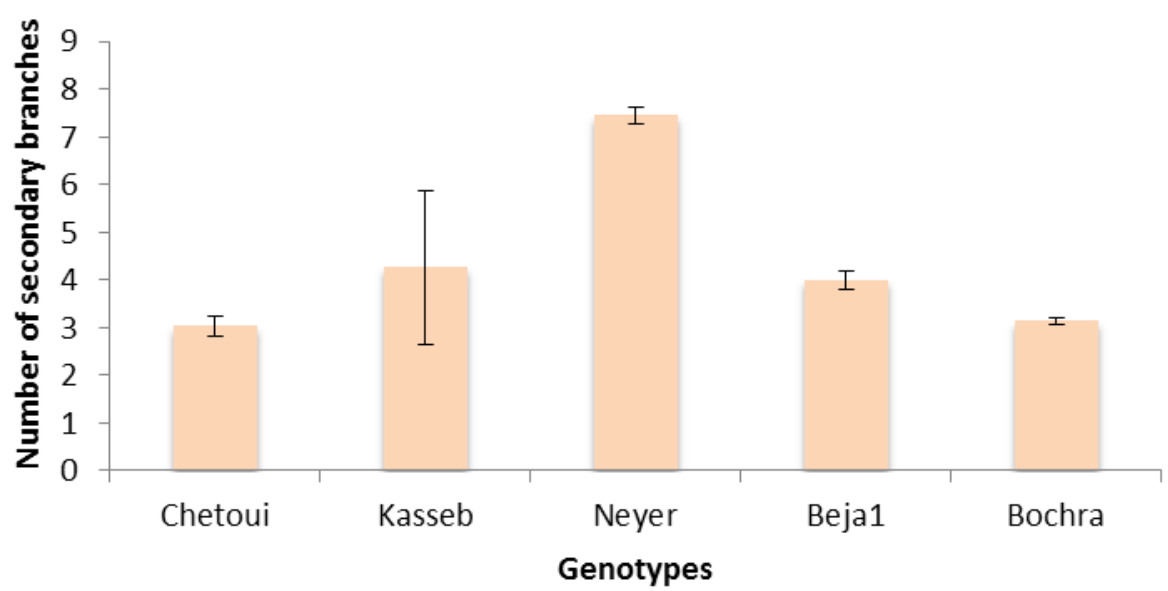

Figure 4. Number of secondary stem branches of five chickpea varieties cultivated at Kef region during 2013-2014 season. The bars indicate standard error of the mean 


\section{Macrothink}

Highly significant variability of number of pods per plant was also found between genotypes (Figure 5). Kasseb, Neyer and Chetoui showed highest values with 51, 41 and 33, respectively. The lowest value of 23 pods per plant was recorded for Beja1 and Bochra cultivars. Gan et al. (2002) reported that the chickpea genotypes with more pods produced high number of grains per plant and have better grains yield.

One hundred seed weight has been considered as an important parameter of chickpea yield potential. Several authors reported that this parameter is highly heritable and presents large variation. It is also used to select better genotypes (Upadhyaya et al., 2001; UPOV, 2005). Kasseb and Chetoui had the lowest values whereas Beja1 had the highest values (Figure 6).

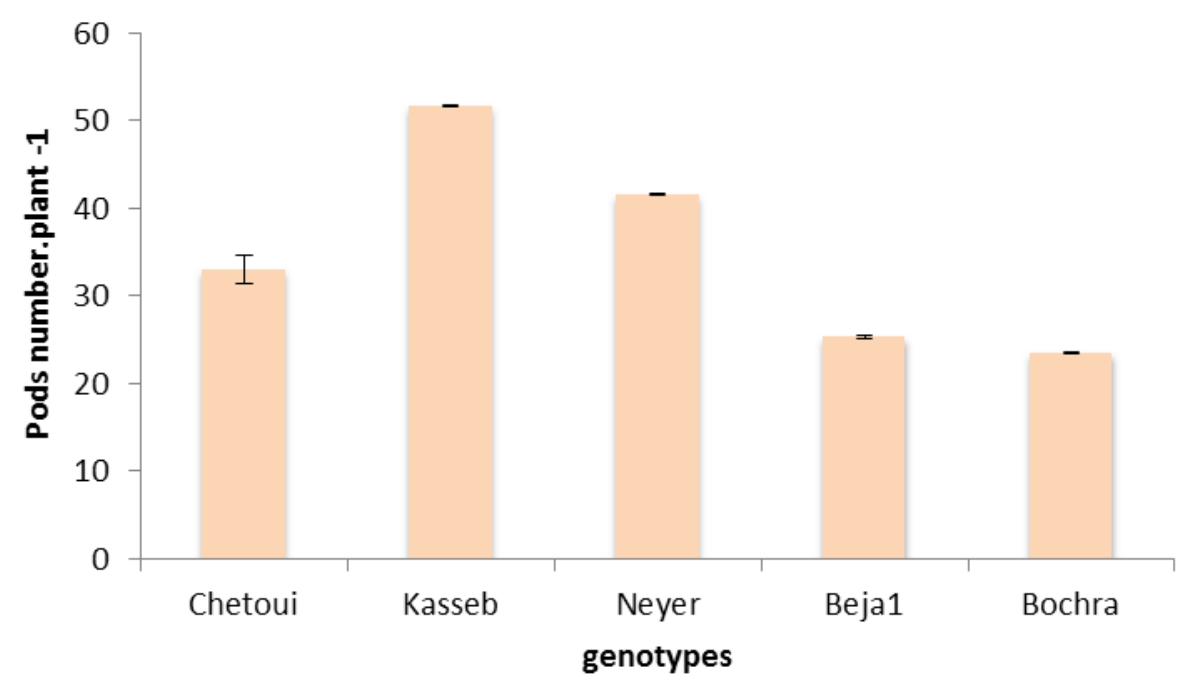

Figure 5. Pods production of five chickpea varieties cultivated at Kef region during 2013-2014 season. The bars indicate standard error of the mean

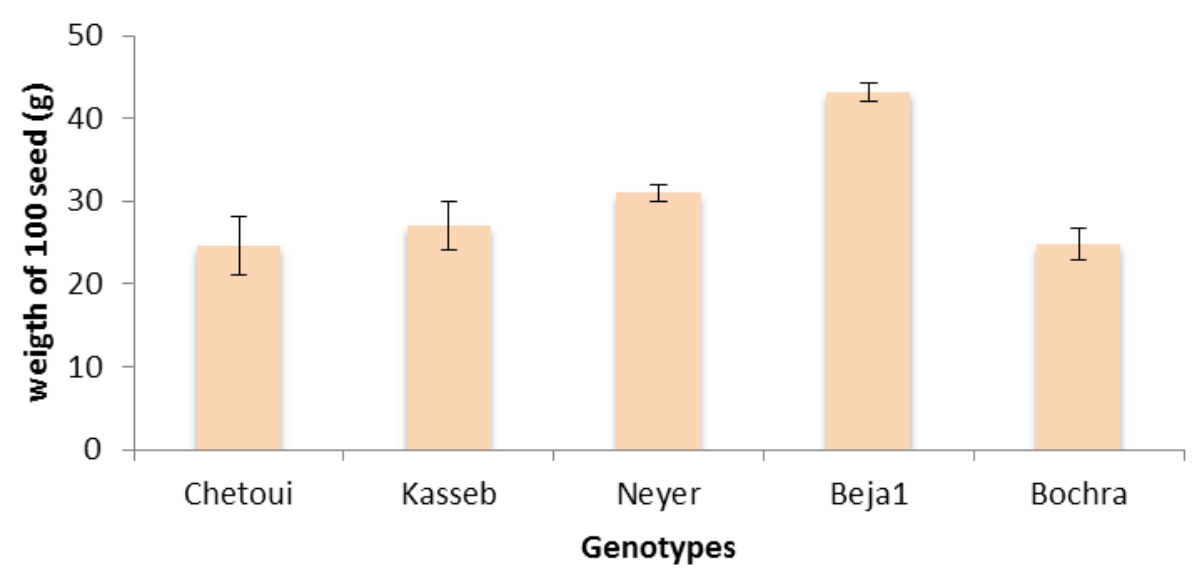

Figure 6. Seed weight of five chickpea varieties cultivated at Kef region during 2013-2014 season. The bars indicate standard error of the mean 


\section{Macrothink}

Journal of Agricultural Studies

ISSN 2166-0379

2017, Vol. 5, No. 1

Seed shape is also an important parameter for morphological characterization of chickpea genotypes. In this regard, Chetoui variety had round seeds compared to irregular shape for the remaining varieties. The Number of grain/plant was also variable for these five varieties of chickpeas. Kasseb, Neyer and Chetoui came in first position with yields of 51 to 33 grains/plant (Figure 7). Bochra had the lowest yields of 23 grains/plant. These results were similar to those reported by Gany et al. (2003) and Liu et al. (2003) who indicated that the production of more pods/unit area is an important factor of seed production for chickpeas. This was also reported by several researchers for several grain legume species (Beech and Leach, 1989; Siddique et al., 1995).

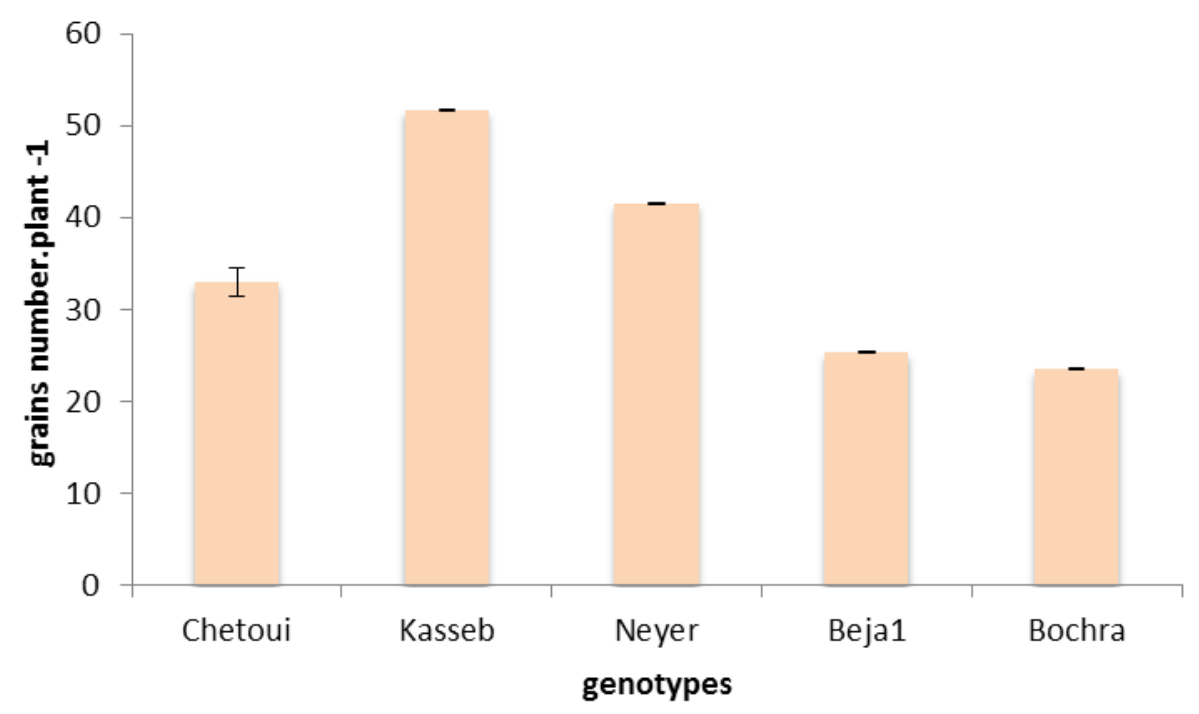

Figure 7. Number of grains per plant of five chickpea varieties cultivated at Kef region during 2013-2014 season. The bars indicate standard error of the mean

\subsection{Biochemical Characterization of Chickpea Varieties}

Protein content values of the five chickpeas varieties ranged from $18 \%$ to $25.48 \%$. Kasseb variety has the highest protein content while Neyer has the lowest (Figure 8). Differences were found for amino acids content of these chickpea varieties (Table 3): aspartic acid, glutamic acid, serine, histidine, glutamine, arginine, glycine, threonine, alanine, valine and methionine, tyrosine, lysine, phénylanine, Isoleucine and Leucine. Glutamic and aspartic acids were predominant in all plant proteins. Bochra variety was the richest in amino acids followed by Chetoui. All the varieties were deficient in sulfur amino acids. Our results were consistent with those found by Wang et al. (2003) who showed that pulses were deficient in sulfur amino acids and tryptophan (Table 3 ). 


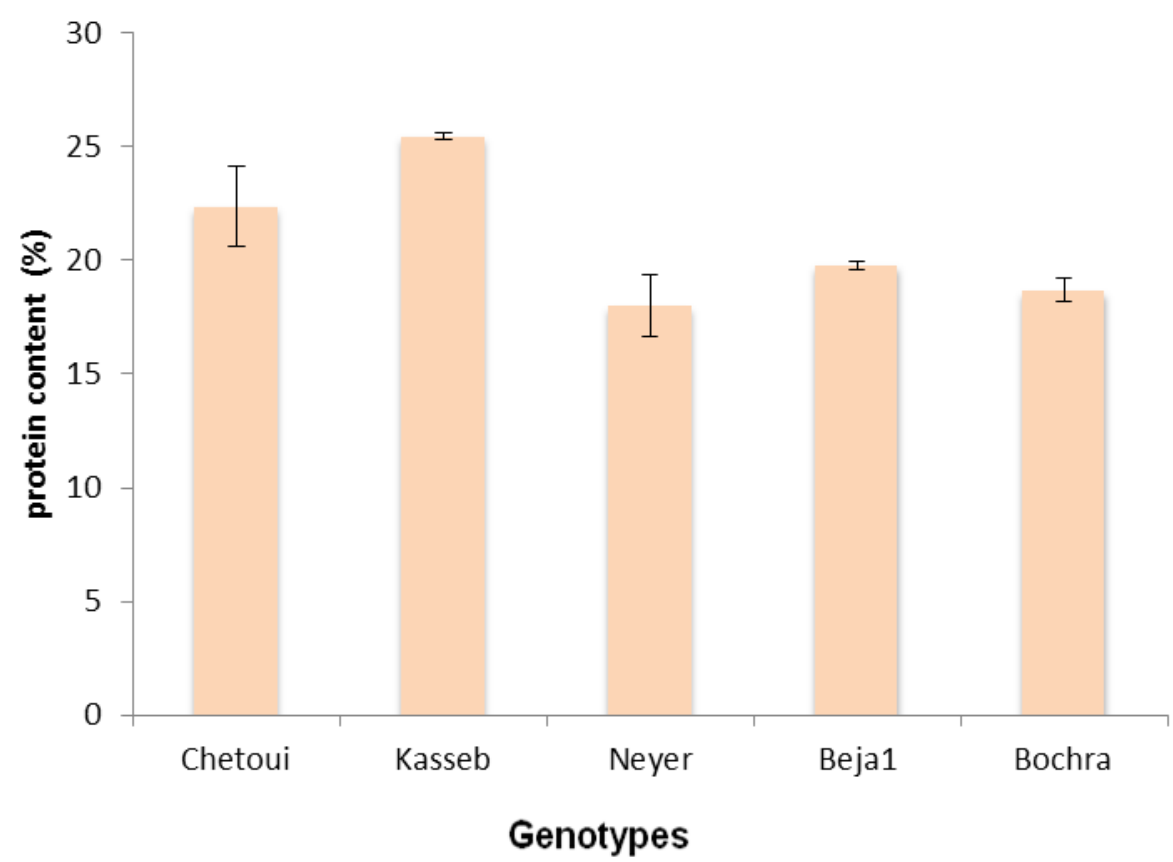

Figure 8. Protein content of five chickpea varieties cultivated at Kef region during 2013-2014 season. The bars indicate standard error of the mean

Table 3. Amino acids content of five Tunisian varieties of chickpea

\begin{tabular}{|c|c|c|c|c|c|}
\hline \multirow[b]{2}{*}{ Amino acids (mg.kg-1) } & \multicolumn{5}{|c|}{ Varieties } \\
\hline & Bochra & Beja1 & Kasseb & Neyer & Chetoui \\
\hline$A S P$ & 569.91 & 68.40 & 62.58 & 65.19 & 163.29 \\
\hline GLUa & 657.87 & 86.14 & 86.19 & 81.31 & 208.19 \\
\hline SER+HIS+ GLU & 123.81 & 55.13 & 40.53 & 49.40 & 39.94 \\
\hline$A R G+G L Y+T H R$ & 160.57 & 150.51 & 144.34 & 144.60 & 57.79 \\
\hline$A L A$ & - & - & - & - & 35.66 \\
\hline$V A L+M E T$ & 49.40 & - & - & - & 20.16 \\
\hline$L Y S$ & 349.45 & 21.66 & 21.58 & 17.96 & 109.83 \\
\hline TYR & 538.91 & 515.76 & 575.74 & 85.04 & 125.31 \\
\hline PHE & 54.30 & 23.04 & 8.90 & 7.40 & 69.68 \\
\hline$I L E$ & 135.43 & 0.79 & 9.92 & 14.27 & 42.37 \\
\hline $\boldsymbol{L E U}$ & 89.48 & 9.18 & 34.26 & 42.99 & 65.99 \\
\hline
\end{tabular}

Aspartic Acid (ASP),Glutamic Acid (GLUa),Serine (SER), Histidine (HIS),Glutamine (GLU),Arginine (ARG), Glycine (GLY),Threonine (THR), Valine (VAL), Alanine (ALA), Methionine (MET), Lysine (LYS), Tyrosine (TYR), Phenylalanine (PHE), IsoLeucine (ILE), Leucine (LEU)

\subsection{Molecular Characterization (DNA profile)}

Similarity indexes were computed for these five varieties of chickpeas. Similarity indexes ranged from $0 \%$ to $100 \%$. Low values indicated that varieties had many dissimilarity and were genetically of remote origins like Kasseb and Neyer, Chetoui and Neyer, Chetoui and Bochra, and Chetoui and Kasseb. But, Bochra and Neyer were of close genetic origins. 
Phylogeny tree (dendrogram) based on genetic similarity matrix using Dice coefficient based on qualitative characteristics (Figure 9) showed different levels of heterogeneity for DNA profiles and polymorphism of the five chickpea varieties. It shows two nodes. The first main node was more polymorphic with two subgroups or clusters of similar varieties such as Neyer and Bochra varieties with 50\% similarities. Beja1, Neyer and Bochra had 25\% of similarity. In second node, Chetoui variety was relatively genetically distant from the others varieties.

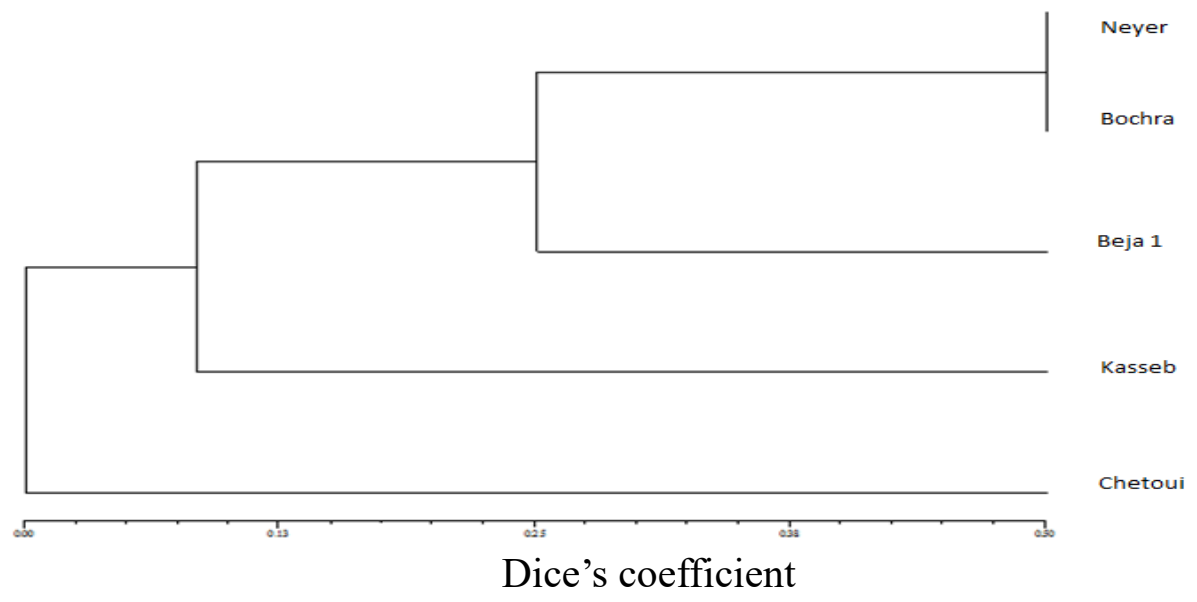

Figure 9. Dendrogram of genetic variability of five Tunisian chickpea varieties using SSR markers and UPGMA analyses

\section{Conclusion}

The present research can be considered as a first characterization of a collection of five Tunisian chickpea varieties. Our results indicated that most of these varieties morphological parameters were genotype dependent. These varieties can be set into two different groups. Bochra and Chetoui made a first cluster of genotypes. The second clustered was made of Kassab, Neyer and Beja1 varieties. Bochra variety was early compared to the other varieties. Large variability was found between these five chickpea genotypes mainly based on number of pods per plant, seed yield per plant, one hundred seeds weight and plant height. Phenotypic differences were also confirmed by molecular and biochemical analysis and they indicated differences between varieties due to genotype origin and phylogeny. Amino acid contents showed that Bochra variety was rich in amino acids with Chetoui variety in second position. All of these chickpea varieties were deficient in sulfur amino acids. These chickpea varieties showed great variability for proteins contents with Kasseb variety being the highest.

\section{References}

AOAC. (1990). Association of Official Analytical Chemists. Official Methods of Analysis, 15th edn. AOAC, Washington. 556.

Beech, D. F., \&. Leach, G. J. (1989). Effect of plant density and row up to 70 plants $/ \mathrm{m}^{2}$ was needed in high yielding (1.5 spacing on the yield of chickpea (cv. Tyson) grown on the Darling Downs, South- Eastern Queensland. Australian Journal of Experimental Agriculture, 29, 241-246. 


\section{MInstitute Macrothink $_{\text {Int }}$}

Journal of Agricultural Studies

ISSN 2166-0379

2017, Vol. 5, No. 1

Ben Mbarek, K. (2011). Comportement du pois chiche (Cicer arietinum L.) du type « kabuli » vis-à-vis du stress hydrique et identification de génotypes tolérants la sécheresse. Thèse de Doctorat en Sciences Agronomiques, 281.

Bouhadida, M., Benjannet, R., Jendoubi W. \& Kharrat, M. (2015). Analysis of genetic diversity of chickpea cultivars using STMS markers._IOSR Journal of Applied Chemistry, 8 (2), 70-74.

Buha, S. M., Panchal, A., Panchal, H., Chambhare, R., Kumar, S., Jain, M., \& Patel P. R. (2011). HPLC-FLD for the Simultaneous Determination of Primary and Secondary Amino Acids from Complex Biological Sample by Pre-column Derivatization. Journal of Chromatographic Science, 49(2), 118-123.

DGPA. (2008). Direction Générale de la Production Agricole. Rapport annuel de suivi des emblavures, Direction des grandes cultures, Ministère de l'agriculture, de l'environnement et des ressources hydrauliques.

DGPA. (2011). Direction Générale de la Production Agricole. Rapport annuel de suivi des emblavures, Direction des grandes cultures, Ministère de l'agriculture, de l'environnement et des ressources hydrauliques.

El Felah, M., \& Kharrat, M. (2014). Evaluation des variétés tunisiennes de pois chiche pour la conduite en pluvial et en irrigué . Actes de la Journée Nationale sur la valorisation des résultats de la Recherche dans le domaine des Grandes Cultures, 94-100.

Gany, T., Miller, P. R., \& McDonald, C. L. (2003). Response of kabuli chickpea to seed size and planting depth. Canadian Journal of Plant Science, 83(1), 39-46.

IRESA. (2014). Institution de la Recherche et de l'Enseignement Supérieur Agricoles. Catalogue des obtentions végétales et des brevets, 53.

Khamassi, K., Chaabane, R., Khoufi, S., Kharrat, M., \& Ben Naceur, M. (2014). Evaluation Agro morphologique de Quelques Génotypes Locaux de Pois Chiche d'Hiver (Cicer arietinum L.) en Tunisie. Journal of New Sciences, 5, 7-19.

Khanna-Chopra, R., \& Sinha, S. K. (1987). Chickpea: physiological aspects of growth and yield. In: The Chickpea. CAB International, (eds. Saxena MC, Singh KB), Wallingford, Oxon, UK, 163-190.

Kharrat, M., \& Ouchari, H. (2011). Faba bean status and prospects in Tunisia. Grain Legumes, $56,11-12$.

Kloosterman, A. D., Budowle, B., \& Daselaar, P. (1993). PCR-amplification and detection of the human D1S80 VNTR locus Amplification conditions, population genetics and application in forensic analysis. International Journal of Legal Medicine, 105, 257-264.

Liu, P. H., Gan, Y., Warkentin, T., \& Mc Donald, C. (2003). Morphological plasticity of chickpea in an semi arid environment. Crop Sciences, 43, 426-429.

Madrid, E., Bouhadida, M., Dolar, S., Kharrat, M., Houasli, C., \& Rubio, J. (2015). Chickpea 
production in Mediterranean Basin. Legume Perspectives, 10, 5-7.

Melki, M., Mhamdi, M., \& Achouri, A. (2011). Chickpea response to low doses of gamma radiation. Russian Agricultural Sciences, 37 (4), 318-321.

Nei, M., \& Li, W. H. (1979). Mathematical model for studying genetic variation in terms of restriction endonucleases. Proceedings of the National Academy of Sciences, 76(10), 5269-5273.

Rohlf, F. J. (2000). NTSYS-pc Numerical Taxonomy and Multivariate Analysis System Version 2.1, Exeter Software, Setauket, NK.

Saghai-Maroof, M. A., Soliman, K. M., Jorgensen, R. A., \& Allard, R. W. (1984). Ribosomal DNA sepacer-length polymorphism in barley: mendelian inheritance, chromosomal location, and population dynamics. Proceedings of the National Academy of Sciences, 81, 8014-8019.

Siddique, K. H. M., Loss, S. P., Regan, K. L., \& Pritchard, D. L. (1998). Adaptation of lentil (Lensculinaris Medik.) to short season Mediterranean-type environments: response to sowing rates. Australian Journal of Agricultural Research, 49, 1057-1066.

Singh, K. B., \& Hawt, G. C. (1979). Winter planting of chickpea. Chickpea Newsletter, 1, 4.

Singh, R., Sharma, P., Varshney, R. K., Sharma, S. K., \& Singh, N. K. (2008). Chickpea improvement: role of wild Chickpea Improvement: Role of Wild Species and Genetic Markers. Biotechnology \& genetic engineering reviews, 25, 267-314.

Upadhyaya, H. D., Bramel, P. J., \& Singh, S. (2001). Development of a chickpea core subset using geographic distribution and quantitative traits. Crop Science, 41 (1), 206-210.

UPOV. (2005). Union Internationale pour la Protection des Obtentions Végétales. Principes directeurs pour la conduite de l'examen de la distinction, de l'homogénéité et de la stabilité. Genève, Switzerland. 35.

Wang, W. X., Brak, T., Vinocur, B., Shoseyov, O., \& Altman, A. (2003). Abiotic resistance and chaperones: possible physiological role of SP1, a stable and stabilising protein from Populus. In: Vasil IK (ed) Plant biotechnology Kluwer, Dordrecht, 439-443.

Winter, P., Pfaff, T., Udupa, S. M., Huttel, B., Sharma, P. C., Sahi, S., Arreguin-Espinoza, R., Weigand, F., Muehlbauer, F. J., \& Kahl, G. (1999). Characterization and mapping of sequence-tagged microsatellite sites in the chickpea (Cicer arietinum L.) genome. Molecular and General Genetics, 262, 90-101.

\section{Copyright Disclaimer}

Copyright for this article is retained by the author(s), with first publication rights granted to the journal.

This is an open-access article distributed under the terms and conditions of the Creative Commons Attribution license (http://creativecommons.org/licenses/by/4.0/). 